\title{
$\mathbb{A}$ Economics Bulletin
}

\author{
Volume 39, Issue 1
}

\section{Economic Complexity and Gender Inequality in Education: An Empirical Study}

\author{
Myriam Ben Saâd \\ PRISM, University of Paris 1, France
}

\author{
Giscard Assoumou-Ella \\ CIREGED, Omar Bongo University
}

\begin{abstract}
Based on the generalized method of moments (GMM) developed by Blundell and Bond (1998), the effect of economic complexity on the Gender Parity Index in education (GPI) is empirically analyzed over the period from 1984 to 2014. The results show, firstly, that the economic complexity positively impacts the GPI at the primary and secondary levels taking into account the global sample. Secondly, they show that it negatively impacts the GPI at the tertiary level in the case of the sample of high-income countries and MENA. They also show that it has a positive effect on the GPI taking into account the global sample, middle-income countries, low-income countries and African countries. Finally, they show that public spending on education, good governance and financial openness reduce gender inequalities at all levels of education in all samples.
\end{abstract}

Citation: Myriam Ben Saâd and Giscard Assoumou-Ella, (2019) "Economic Complexity and Gender Inequality in Education: An Empirical Study", Economics Bulletin, Volume 39, Issue 1, pages 321-334

Contact: Myriam Ben Saâd - myriambensaad@yahoo.fr, Giscard Assoumou-Ella - g.assoumouella@gmail.com.

Submitted: September 22, 2018. Published: February 18, 2019. 


\section{Introduction}

The 20th century was marked by a general movement for gender equality. While this has created better opportunities for women in countries with advanced economies, gender equality remains a distant goal in most developing countries. According to UNESCO data, the percentage of girls in the global out-of-school population was 50\% in 2017. However, this global average hides regional and national disparities. Indeed, these data also show that girls of primary school age are at a disadvantage in most developing countries.

In the literature, it is shown that foreign trade has a significant effect on gender inequality in education (ILO, 2004; Korinek, 2005; Arora, 2012). However, this work does not take into account the economic complexity ${ }^{1}$. According to Hidalgo and Hausmann (2009), the complexity of a country's exports integrates the level of diversification of this country, as well as their value-added and their degree of sophistication. As a result, the productivity of an economy resulting from the diversity of its productive capacities and the differences in per capita income between countries could be explained by the differences in economic complexity (Hausmann et al, 2007; McMillan and Rodrik, 2011; Aditya and Acharyya, 2012; Felipe et al, 2012). Thus, the complexity of a country's exports positively influences the growth of its per capita output (Felipe et al. 2012; Jankowska et al. 2012; Poncet and De Waldemar, 2013; Péridy et al, 2016). Also, many empirical studies have found a relationship between economic growth and gender inequality (Klasen and Lamanna, 2009; Mitra et al, 2015).

In this context, a causal link could be established between the economic growth driven by the complexity of a country's exports and gender inequalities in education. Our research program consists in empirically proving the existence of this causal relationship in order to propose economic policy measures.

The interest of conducting such a study is essentially derived from Sen's work (1999) which posits that keeping women out of the education system makes the world less fair and less secure, while reducing the well-being the society. As a result, it seems important to look for factors that could enable a country to fight against this phenomenon. The economic complexity could be one of them.

Thus, the research hypothesis is to assume that the complexity of the exports could lead to a decrease in gender inequalities in education. Indeed, an increase in trade resulting from the complexity of the exports could favor women's access to the labor market (Korinek, 2005). As a result, they would invest in their children's education (World Bank, 2001). In addition, the decrease in gender inequalities in education makes the economy more productive (Assoumou-Ella, 2018). Thus, to diversify its exports, the government will have to invest in the education system by reducing this type of inequality.

\footnotetext{
${ }^{1}$ According to Hausmann and Hidalgo (2009), economic complexity refers to the availability of "productive capacities" within an economy, and especially to the ability of the economy to optimally combine these different capabilities in order to create high value-added and sophisticated products.
} 
We are based on the United Nations Educational, Scientific and Cultural Organization (UNESCO) approach for measuring inequality. The Gender Parity Index in education (GPI) ${ }^{2}$ is calculated for the primary, secondary, primary and secondary, and higher levels. A GPI below 1 means that there is inequality in favor of men in terms of schooling. Perfect equality is represented by an index equal to 1 . In terms of economic complexity, we use the indicator developed by Hidalgo and Hausmann (2009). It is measured using a theoretical index based on trade data combining the level of diversification and the degree of sophistication of the products exported by a country.

We use the Generalized Method of Moments (GMM) developed by Blundell and Bond (1998) to analyze the effect of the complexity of exports on gender inequalities in education. This method has the advantage of allowing the control of the individual and temporal effects and the correction of the endogeneity bias of the variables.

This work makes four main contributions. First, it is shown that economic complexity has a positive effect on the GPI at the primary and secondary levels taking into account the global sample. Second, it is shown that economic complexity negatively impacts the GPI at the tertiary level in the sample of high-income countries and MENA. Third, it is shown that economic complexity has a positive effect on the GPI at the tertiary level taking into account the global sample, middle-income countries, low-income countries and African countries. Finally, public expenditure on education, good governance and financial openness is shown to reduce gender inequalities at all levels of education in all samples.

The rest of the study is presented as follows: Section 2 is a brief review of the literature. In sections 3, 4 and 5, we present the descriptive analysis of the data, the empirical analysis and the conclusion.

\section{Selected Literature Review}

In recent works, a causal link between gender inequality, economic growth and export diversification has been established (Tansel and Gungor, 2012; Barro, 2013; Hassan and Cooray, 2013). This section focuses on studies that analyze the effect of export-led economic growth on gender inequality in education. In this work, it is suggested that this causality can be indirect via the increased income of women (Korinek, 2005; ILO, 2004) or direct (Arora, 2012; Sajid, 2014; Yamamuna, 2016).

The link between export-led economic growth and gender inequality in education exists through increased income for women. Indeed, working women invest in the education of their children. Hoddinott and Haddad (1995) and World Bank (2001) show that households where women with higher incomes than men invest more in education, health and nutrition for children. A case study conducted in Brazil showed that infant mortality declines in households where women's incomes increase. Nutrition and schooling of children also increase in these households (Thomas, 1990; Thomas et al, 1997). In Ivory Coast, the increase in women's household incomes leads to an increase in the budget allocated to nutrition and education, to the detriment of alcohol and cigarettes (Khander, 1998; Pitt and Khandker,

\footnotetext{
${ }^{2}$ One of the limitations of this index is that it does not show what is causing the improvement or deterioration of the conditions of women or men.
} 
1998). Thus, it is possible to establish a link between women's incomes and gender equality in education. Indeed, women's access to the labor market through economic growth driven by foreign trade could have a positive effect on children's human capital and well-being. As a result, Barro (1997) argues that more educated women have more educated children. This increases the share of educated workers in society. In the same vein, Hill and King (1995) show that a 10 percentage point increase in female enrollment in primary education results in a decrease of 4.1 percentage points of death per 1,000 births. The same increase in secondary education results in a 5.6 percentage point decrease in deaths. For their part, BaliamouneLutza and Bokoc (2013) show that income is the main determinant of human development, measured in terms of literacy and life expectancy.

In this context, since foreign trade promotes economic growth, and economic growth leads to lower gender inequalities in education through increased income for women, an indirect link between trade and gender inequality can be established. Indeed, some studies argue that foreign trade increases the number of women in jobs in export-oriented sectors. This leads to changes in lifestyle and traditional institutions. These changes are good for women because of the increase in their income. Korinek (2005) shows that integration into international trade has a positive effect on gender equality in education. Indeed, an increase in women's jobs in sectors oriented towards international trade provides them with a surplus of purchasing power enabling them to increase investment in education for future generations. According to the ILO (2004), globalization can lead to changes in the way of life and traditional institutions. These changes in tradition can have positive and negative effects on gender inequality. The management practices of developed countries are introduced in developing countries; leading to greater gender equality. Thus, with regard to the discriminatory practices that can be observed in local businesses, more educated women prefer to work in the branches of multinational enterprises. In the medium and long term, the practices of multinational firms are progressively introduced in the management of local firms leading to more gender equality.

With regard to the direct link between foreign trade and gender inequalities in education, there is no consensus in the literature. Badji (2008), in a sample of countries in the West African Economic and Monetary Union (WAEMU), shows that globalization has a positive impact on gender equality in education through foreign direct investment, and that opening up of portfolio and banking investments contributes to increasing inequalities. In the same perspective, Schultz (2006) uses a sample of 70 countries over the period from 1965 to 1980 to show that an increase in tariffs, quotas and restrictions on foreign trade leads to a decline in the level of education of women and their access to health. On the other hand, liberalization of trade policies leads to greater capital accumulation and greater gender equality. For his part, Sajid (2014) wants to know if trade openness promotes gender equality in education in the D8 countries (Bangladesh, Egypt, Indonesia, Iran, Malaysia, Nigeria, Pakistan and Turkey) for the period from 1980 to 2012. The coefficient of the trade variable is significant at $1 \%$ and there is a positive impact on the ratio of girls' enrollment to boys' at primary, secondary and tertiary levels. Yamamuna (2016) uses cross-country data to measure the effect of trade openness in 1970 on inequality in 2011. They show that trade openness has reduced gender inequalities in wage and educational attainment. As for education, the effect of openness on inequality disappeared in 2000 and this result is robust after controlling for the endogeneity bias. Unlike previous studies, Forsythe et al. (2003), Verschuur and Reysoo (2003), Arora (2012) and Baliamoune-Lutz (2006) generally find a negative effect. Indeed, Verschuur and Reysoo (2003) analyze the impact of liberalism on social well-being, health and educational social services. The study finds a negative effect of structural adjustment policies on the situation of women in access to education compared to that of men. Menon and Yana Van der 
Meulen (2009) document that increases in openness to trade in India leads to a larger gender gap. In the same vein, Arora (2012) studies the impact of globalization on gender inequalities in the states of India. He finds that most states with a higher openness index have more gender inequalities in education. Baliamoune-Lutz (2006), using cross-sectional data, argues that globalization and growth do not affect gender equality in developing countries in North Africa. The situation differs, however, in sub-Saharan African countries where the impact is negative. In the same sense, Forsythe et al. (2003) found that open trade policies have no impact on gender inequality in education. It is rather public spending on education that mitigates this type of gender inequality.

The existing literature opens several interesting perspectives. However, there is no analysis of the link between foreign trade based on the complexity of exports and gender inequalities in education. This article aims to enrich the literature by adding this component.

\section{Data description: evolution of gender inequality in education from 1984 to 2014 and scatter plot}

Data used in this study come from the World Bank (online database: Human Development Indicators and Gender Statistics) and the 2015 Economic Complexity Atlas. We used the extrapolation method to fill in the missing data. The study period extends from 1984 to 2014 . To make a description of the distribution of gender inequalities in education, we do a mapping analysis and a scatter plot.

\subsection{Cartography}

Figures 1, 2, 3 and 4 are mappings and histogram comparing gender inequalities in education observed in 1984 and 2014.

Figure 1: Cartography of the gender parity indexes in primary and secondary level enrollment, 1984-2014

1984

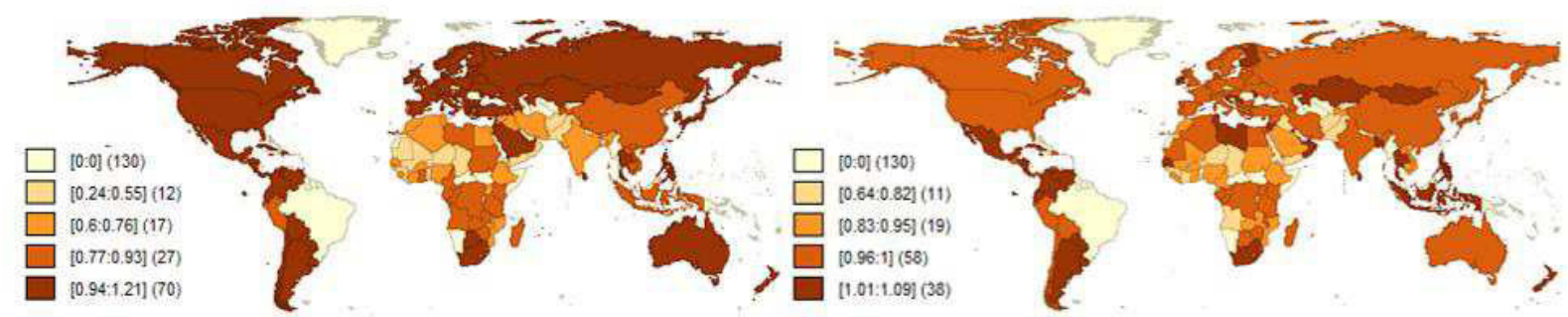

Source: Author's calculations based on World Bank (Online database: World Development Indicators and Gender Statistics) dataset.

According to Figure 1, North America, a large part of European countries and Australia have the same evolution. In 1984, their indices were between 0.94 and 1.21. In 2014, the indices were between 0.96 and 1 . Thus, we can see that the evolution of these countries is positive because they were more egalitarian in 2014 compared to their situation in 1984. In Central and South America, excluding Brazil, the evolution is almost the same. The indexes were 
between 0.94 and 1.21 in 1984 and between 1.01 and 1.09 in 2014. Brazil is the country with the most inequality in this region. Its situation was the same between 1984 and 2014. In Africa, there is no homogeneity of situations. Libya, Sudan and most of the Central and East African countries had indexes between 0.77 and 0.93 in 1984. In 2014, the situation in Sudan deteriorated. This can be explained by the civil wars in these countries.

Figure 2: Cartography of the gender parity indexes in tertiary level enrollment, 19842014.
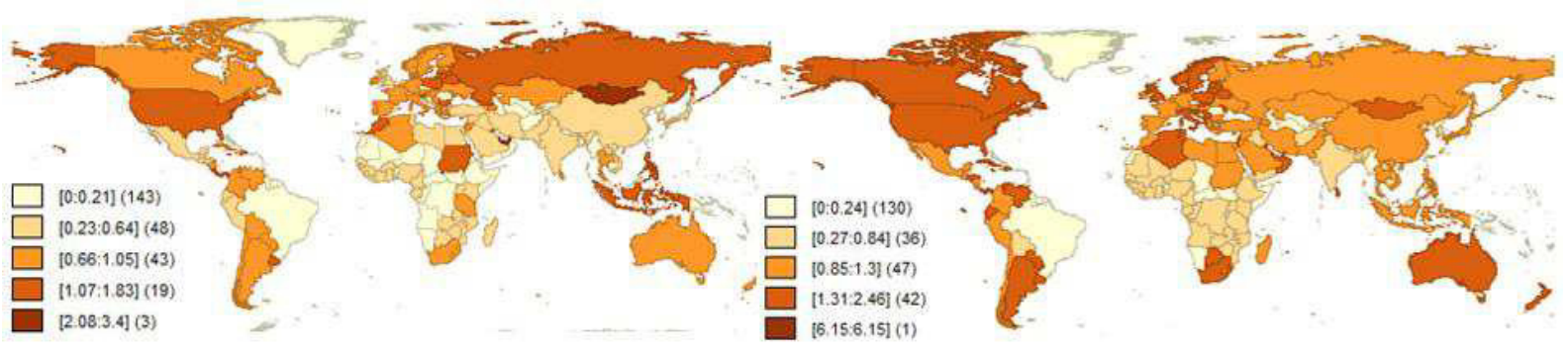

1984

2014

Source: Author's calculations based on World Bank (Online database: World Development Indicators and Gender Statistics) dataset.

According to Figure 2, in tertiary education, Africa is the continent with the most inequality. Central America improved its situation with an index of between 0.23 and 0.64 in 1984 and between 0.85 and 1.3 in 2014. There is also a change in the situation in Canada. This country had an index between 0.66 and 1.05 in 1984. Its index is between 1.31 and 2.46 in 2014 . There is therefore inequality in favor of women in this country. In general, we observe that there is more inequality in the world in tertiary enrollments than in the enrollment at the primary and secondary levels.

Figure 3 \& 4: School enrollment, primary \& secondary, tertiary (gross), gender parity index (GPI)

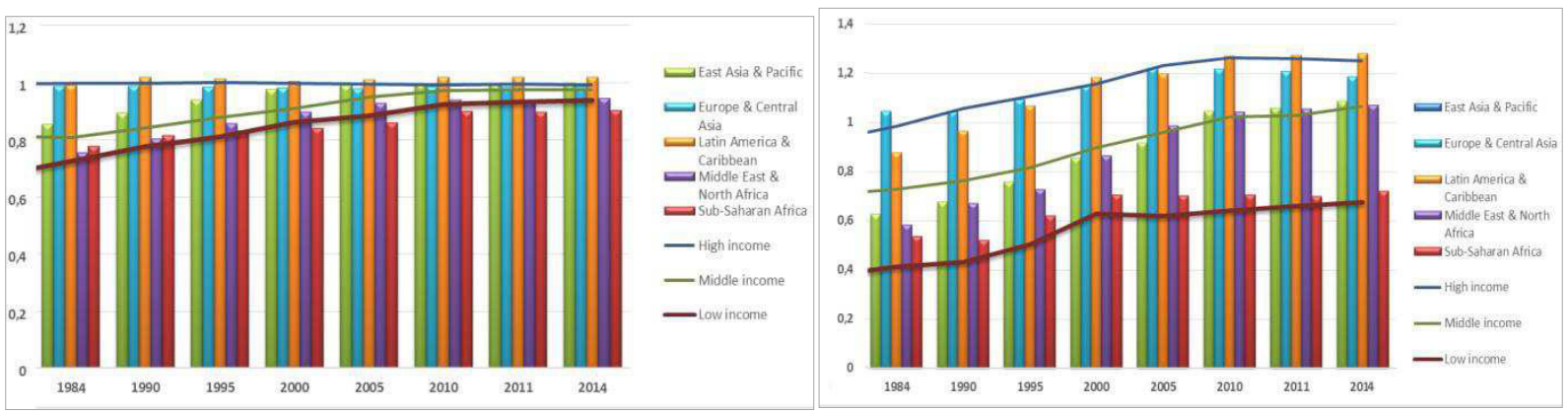

Source: Author's calculations based on World Bank data (Online database: World Development Indicators and Gender Statistics, 2016) 
Cartography is a presentation of inequalities in the world according to the countries. The histogram approach (Figure 3 and 4) groups the countries by continent and levels of development. To this end, we note that Latin American countries are more egalitarian in primary and secondary education, followed by countries in Europe and Asia. The African continent is the most unequal. However, inequalities decrease over time. By analyzing levels of development, there is perfect equality in high-income countries. Middle-income countries are unequal, but less than low-income countries.

With regard to higher education, Figure 3 and 4 show that the index has been above 1 in Europe, Latin America and North Africa (since 2010). So there is inequality in favor of women in these countries. Asian countries have become egalitarian since 2010. Those in subSaharan Africa remain the most unequal in favor of men. The analysis in terms of income level shows that the index has been above 1 since the 1990s in high-income countries. This reflects inequality in favor of women in these countries. Low-income countries remain the most unequal in favor of men.

\subsection{Scatter plot}

Figure 5 \& 6: Relation between economic complexity and gender inequality in primary and secondary level enrollment and tertiary level enrollment (1984-2014).
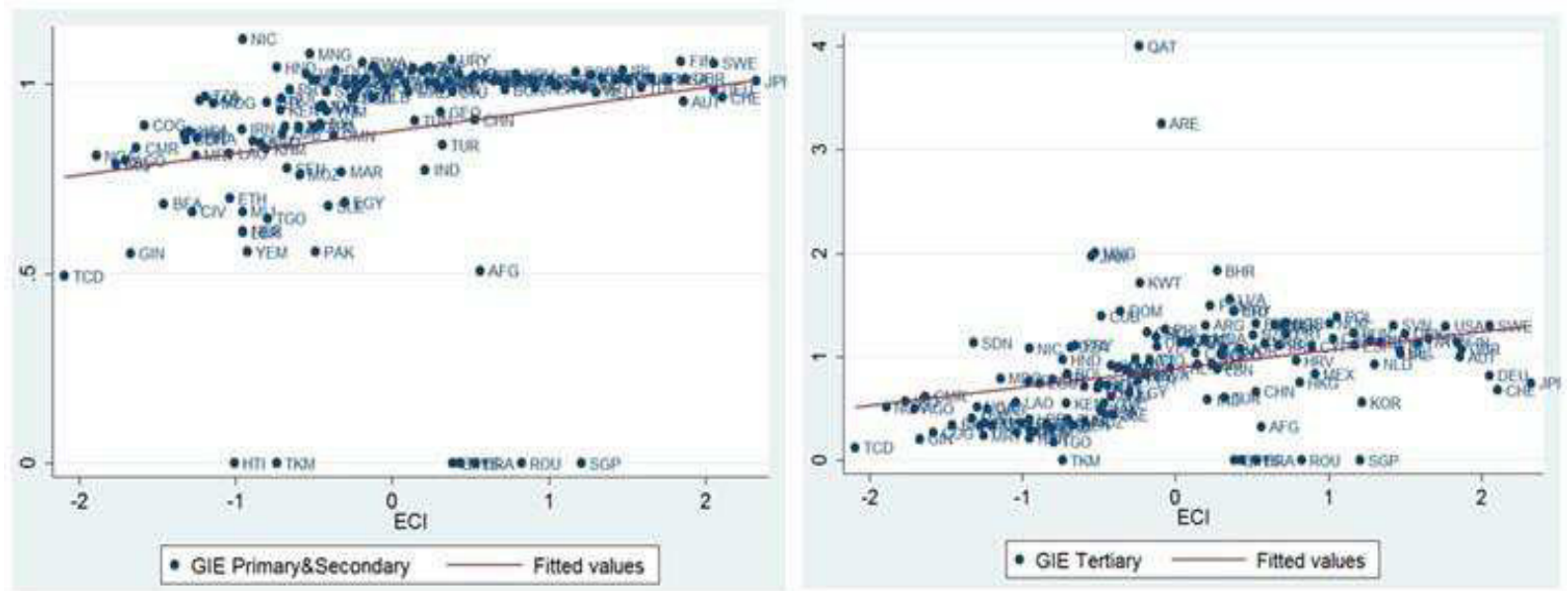

Source: Author's calculations based on World Bank (Online database: World Development Indicators and Gender Statistics) and The Atlas of Economic Complexity, 2016.

Following the presentation of the maps of the evolution of gender inequalities in the world by comparing the situations of 1984 and 2014, Figures 5 and 6 are scatter plots that show the correlation over time between gender inequalities in education and the economic complexity index. To this end, with a few exceptions, there is a strong correlation between inequality and economic complexity in Figure 6. A straight line can be drawn representing this correlation in the two point clouds. But in Figure 5, we observe that most of the points are above the straight line. This may represent a lack of correlation between gender inequality in primary and 
secondary enrollment, and economic complexity. However, correlation does not mean causation. This is why in section 4 we perform an empirical analysis.

\section{Empirical model and results}

The literature shows that foreign trade has a significant effect on gender inequality in education. However, it does not reach a consensus on the causal meaning of this effect. Some authors find a positive relationship (Schultz, 2006; Sajid, 2014), while others find a negative relationship (Menon and Yana Van der Meulen, 2009; Arora, 2012). Thus, we make the hypothesis that the complexity of exports can resolve this ambiguity. In this context, we use the neoclassical theory as a theoretical frame of reference. As argued in Borjas and Ramey (1995) and others, an increase in foreign trade should reduce the wage gap between men and women. Moreover, as the literature has shown, the higher the income of women, the more they invest in children's education, health and nutrition (Hoddinott and Haddad, 1995; World Bank, 2001), which leads to a decrease in gender inequality in education. So to take into account the endogeneity resulting from this causality, we include the gap between genders in relation to the access to the labor market (measured by the gender ratio of labor force participation rates) and gross domestic product (GDP) in instrumental variables. Thus, we formalize the empirical equation as follows:

$\log P_{P I, t}=\alpha \log G P I_{i, t-1}+\beta^{\prime} \log X_{i, t}+u_{i}+v_{t}+e_{i, t}$

Where, $\log G P I$ represents the logarithm of the gender inequality index in education (primary and secondary). $X$ contains the explanatory variables (the economic complexity index $(\log E C I)^{3}$, public expenditure on education as \% of GDP $(\log E d u c)$, government stability $(\log G o u v)$, foreign direct investment in percentage of GDP $(\log I D E)$, membership in the WTO (WTO), $u$ specific country effect, $v$ the specific temporal effect and the error term e. $i$ is the country index and $t$ the time index. The measure of economic complexity used in this study is that developed by Hidalgo and Hausmann (2009). In addition, political factors such as the quality of governance are taken into account (Anderson and Konard 2003a, 2003b; Baskaran and Hessami, 2012). Also, regions or countries participate in international trade in accordance with their bilateral and multilateral agreements (Anderson and Konard 2003a, 2003b; Baskaran and Hessami, 2012). For this purpose, we specify membership in the World Trade Organization (WTO) for a country. In addition, the FDI and public investment in education (Educ) are expected to influence gender inequality in education (Selden and Wasylenko, 1995; Esim, 2000; Forsythe et al, 2003; Braunstein, 2006).

Note that there is a second empirical equation containing gender inequality at the tertiary level of education as a dependent variable. Since the variables are not co-integrated, the presence of the lagged variable leads us to use the generalized method of moments (GMM) in systems, developed by Blundell and Bond (1998). It has the advantage of allowing the control of individual and temporal specific effects, while correcting the endogeneity bias. The ultimate goal is to check the validity of the instruments. To check their validity, we rely on the Sargan test. We also verify the absence of autocorrelation of the residues. In addition, Roodman

\footnotetext{
${ }^{3}$ Also, using of logarithm allowed us to interpret the results in terms of elasticity. Thus, we added +3 to all data to remove negative signs of certain variables.
} 
(2009) suggests that many instruments can weaken the Hansen test. Thus, using the command xtabond2 in Stata, we retain only two instrumental variables: GDP and the gender gap in relation to access to the labor market. An estimate using an alternative method (estimate IV) was carried out and confirms the results. Therefore, we can conclude to their robustness.

Table 1: Impact of economic complexity on gender parity index in primary and secondary level enrollment, 1984-2014.

\begin{tabular}{|c|c|c|c|c|c|c|}
\hline $\log P_{I_{i t}}$ & $\begin{array}{c}\text { (1) } \\
\text { Total }\end{array}$ & $\begin{array}{c}(2) \\
\text { High } \\
\text { income }\end{array}$ & $\begin{array}{c}\text { (3) } \\
\text { Middle } \\
\text { income }\end{array}$ & $\begin{array}{c}(4) \\
\text { Low } \\
\text { income }\end{array}$ & $\begin{array}{c}(5) \\
\text { Africa }\end{array}$ & $\begin{array}{c}\text { (6) } \\
\text { MENA }\end{array}$ \\
\hline $\log G P I_{i t-1}$ & $\begin{array}{c}0.354 * * * \\
(0.0122)\end{array}$ & $\begin{array}{l}0.752 * * * \\
(0.00885)\end{array}$ & $\begin{array}{c}0.338 * * * \\
(0.0172)\end{array}$ & $\begin{array}{c}0.858 * * * \\
(0.0162)\end{array}$ & $\begin{array}{c}0.883 * * * \\
(0.0115)\end{array}$ & $\begin{array}{c}0.363 * * * \\
(0.0300)\end{array}$ \\
\hline $\log E C I_{i t}$ & $\begin{array}{l}0.0117 * * \\
(0.00462)\end{array}$ & $\begin{array}{r}-0.000104 \\
(0.00139)\end{array}$ & $\begin{array}{c}0.0104 \\
(0.00858)\end{array}$ & $\begin{array}{c}0.00280 \\
(0.00342)\end{array}$ & $\begin{array}{c}0.00293 \\
(0.00198)\end{array}$ & $\begin{array}{l}0.00185 \\
(0.0141)\end{array}$ \\
\hline $\operatorname{logEduc}_{\mathrm{it}}$ & $\begin{array}{c}0.00759 * * * \\
(0.00169)\end{array}$ & $\begin{array}{l}-7.75 \mathrm{e}-05 \\
(0.000429)\end{array}$ & $\begin{array}{c}0.0103 * * * \\
(0.00319)\end{array}$ & $\begin{array}{l}0.00351 * * \\
(0.00154)\end{array}$ & $\begin{array}{l}0.00220 * * \\
(0.000895)\end{array}$ & $\begin{array}{l}-0.00496 \\
(0.00539)\end{array}$ \\
\hline $\operatorname{logGouv} v_{\text {it }}$ & $\begin{array}{c}0.00676 * * * \\
(0.00142)\end{array}$ & $\begin{array}{c}0.000751 \\
(0.000470)\end{array}$ & $\begin{array}{c}0.00950 * * * \\
(0.00248)\end{array}$ & $\begin{array}{c}0.00232 \\
(0.00148)\end{array}$ & $\begin{array}{c}0.00322 * * * \\
(0.000865)\end{array}$ & $\begin{array}{c}0.0224 * * * \\
(0.00541)\end{array}$ \\
\hline $\operatorname{logIDE} E_{i t}$ & $\begin{array}{c}6.50 \mathrm{e}-05 \\
(0.000150)\end{array}$ & $\begin{array}{l}-9.96 \mathrm{e}-06 \\
(3.52 \mathrm{e}-05)\end{array}$ & $\begin{array}{l}-0.000332 \\
(0.000288)\end{array}$ & $\begin{array}{c}0.000477 * * * \\
(0.000156)\end{array}$ & $\begin{array}{c}0.000244 * * * \\
(7.32 \mathrm{e}-05)\end{array}$ & $\begin{array}{c}-9.99 \mathrm{e}-05 \\
(0.000429)\end{array}$ \\
\hline WTO $_{\text {it }}$ & $\begin{array}{c}0.000168 \\
(0.000889)\end{array}$ & $\begin{array}{c}-0.000518 * * \\
(0.000214)\end{array}$ & $\begin{array}{l}-0.00253 \\
(0.00177)\end{array}$ & $\begin{array}{c}0.00244 * * \\
(0.00101)\end{array}$ & $\begin{array}{c}0.000874 \\
(0.000535)\end{array}$ & $\begin{array}{r}-0.000793 \\
(0.00345)\end{array}$ \\
\hline Constant & $\begin{array}{l}0.156 * * * \\
(0.00398)\end{array}$ & $\begin{array}{c}0.0727 * * * \\
(0.00263)\end{array}$ & $\begin{array}{l}0.158 * * * \\
(0.00621)\end{array}$ & $\begin{array}{l}0.0255 * * * \\
(0.00352)\end{array}$ & $\begin{array}{l}0.0239 * * * \\
(0.00272)\end{array}$ & $\begin{array}{c}0.154 * * * \\
(0.0111)\end{array}$ \\
\hline Observations & 3990 & 1,440 & 1,710 & 840 & 900 & 570 \\
\hline Nb country & 133 & 48 & 57 & 28 & 30 & 19 \\
\hline $\begin{array}{l}\text { Sargan test (p- } \\
\text { value) }\end{array}$ & 0.12 & 0.17 & 0.09 & 0.11 & 0.08 & 0.1 \\
\hline $\operatorname{AR}(\mathbf{1})$ & 0.04 & 0.0002 & 0.01 & 0.04 & 0.001 & 0.02 \\
\hline $\operatorname{AR}(2)$ & 0.28 & 0.12 & 0.25 & 0.45 & 0.73 & 0.49 \\
\hline
\end{tabular}

Standard errors in parentheses

$* * * \mathrm{p}<0.01, * * \mathrm{p}<0.05, * \mathrm{p}<0.1$

Table 2: Impact of economic complexity on gender parity index in tertiary level enrollment, 1984-2014.

\begin{tabular}{lcccccc}
\hline $\operatorname{LogGPI}_{\mathbf{i t}}$ & $\begin{array}{c}(1) \\
\text { Total }\end{array}$ & $\begin{array}{c}\text { High } \\
\text { income }\end{array}$ & $\begin{array}{c}\text { Middle } \\
\text { income }\end{array}$ & $\begin{array}{c}\text { Low } \\
\text { income }\end{array}$ & $\begin{array}{c}(5) \\
\text { Africa }\end{array}$ & $\begin{array}{c}(6) \\
\text { MENA }\end{array}$ \\
\hline logGPI $_{\text {it-1 }}$ & $0.620^{* * *}$ & $0.817^{* * *}$ & $0.528^{* * *}$ & $0.808^{* * *}$ & $0.723^{* * *}$ & $0.856^{* * *}$ \\
& $(0.00926)$ & $(0.0140)$ & $(0.0136)$ & $(0.0187)$ & $(0.0177)$ & $(0.0190)$ \\
$\operatorname{logECI}_{\mathbf{i t}}$ & $0.0126^{* *}$ & $-0.0489^{* * *}$ & $0.0224 * * *$ & $0.0108^{*}$ & $0.0161^{* *}$ & $-0.0126^{*}$ \\
& $(0.00603)$ & $(0.0138)$ & $(0.00704)$ & $(0.00734)$ & $(0.00694)$ & $(0.00165)$ \\
$\operatorname{logEduc}_{\mathbf{i t}}$ & 0.00167 & 0.000503 & 0.00293 & $0.00929^{* * *}$ & $0.0123^{* * *}$ & -0.00404 \\
& $(0.00202)$ & $(0.00384)$ & $(0.00252)$ & $(0.00327)$ & $(0.00308)$ & $(0.00619)$ \\
$\operatorname{logGouv}_{\mathbf{i t}}$ & $0.0263^{* * *}$ & $0.0310^{* * *}$ & $0.0149^{* * *}$ & $0.0104 * * *$ & $0.0180^{* * *}$ & $0.0239^{* * *}$ \\
& $(0.00191)$ & $(0.00495)$ & $(0.00211)$ & $(0.00329)$ & $(0.00319)$ & $(0.00767)$ \\
$\operatorname{logIDE}_{\mathbf{i t}}$ & $0.000527 * * *$ & 0.000150 & $0.000782^{* * *}$ & $0.000555^{*}$ & $0.00123^{* * *}$ & 0.000782 \\
& $(0.000180)$ & $(0.000334)$ & $(0.000221)$ & $(0.000321)$ & $(0.000258)$ & $(0.000528)$ \\
$\mathbf{W T O}_{\mathbf{i t}}$ & $0.00911^{* * *}$ & -0.00202 & $0.0179 * * *$ & 0.00199 & -0.000102 & -0.00267 \\
& $(0.00114)$ & $(0.00205)$ & $(0.00148)$ & $(0.00211)$ & $(0.00185)$ & $(0.00429)$
\end{tabular}




\begin{tabular}{|c|c|c|c|c|c|c|}
\hline Constant & $\begin{array}{l}0.0552^{* * * *} \\
(0.00372)\end{array}$ & $\begin{array}{c}0.0552^{* * *} \\
(0.0101)\end{array}$ & $\begin{array}{l}0.0782 * * * \\
(0.00449)\end{array}$ & $\begin{array}{c}0.00530 \\
(0.00414)\end{array}$ & $\begin{array}{l}0.00813^{* *} \\
(0.00383)\end{array}$ & $\begin{array}{r}0.0237 * * * \\
(0.0110)\end{array}$ \\
\hline Observations & 3990 & 1,440 & 1,710 & 840 & 900 & 570 \\
\hline Nb country & 133 & 48 & 57 & 28 & 30 & 19 \\
\hline $\begin{array}{l}\text { Sargan test (p- } \\
\text { value) }\end{array}$ & 0.14 & 0.16 & 0.09 & 0.076 & 0.17 & 0.2 \\
\hline $\operatorname{AR}(\mathbf{1})$ & 0.001 & 0.006 & 0.01 & 0.01 & 0.03 & 0.02 \\
\hline $\mathbf{A R}(2)$ & 0.53 & 0.52 & 0.53 & 0.12 & 0.16 & 0.35 \\
\hline
\end{tabular}

To analyze the effect of the economic complexity on gender inequality in education, we used six different samples: the world sample, high-income countries, middle-income countries, low-income countries, and African and MENA countries (Appendix).

The first observation we can make concerning the results of tables 1 and 2 is that all p-value of the Sargan test is greater than 0.05. Thus, we cannot reject the null hypothesis H0 of validity of the instruments. Also, the AR (1) effect of the residuals is accepted and the AR (2) effect is rejected. We conclude that there is an absence of serial correlation of the residuals.

The second observation is that there is self-perpetuation of the inequalities, both in primary and secondary or tertiary education. In fact, the lags of gender parity indexes in year $t-1$ have positive and significant effects on the level of the inequalities in year $t$. Thus, declining inequality in year $t-l$ has a positive effect on gender equality in education in year $t$. In other words, governments must reduce inequality in the lower levels of education to fight against this phenomenon in the higher levels of education. The increase in gender parity index means that there is an improvement in the situation of women in terms of accessibility to education. As a result, any variable that has a positive effect on this index improves women's situations, and vice versa.

The third observation is that, apart from the global sample, the economic complexity has no effect on gender inequality in primary and secondary level enrollment. This empirical result confirms the observation of no correlation in the Figure 5. This can be explained by the fact that a complex economy needs a more skilled workforce. Thus, the workers most concerned are those with a high level of education. In this context, we find a significant effect of the economic complexity on the inequalities in tertiary level enrollment. The sign is positive for the global sample, the middle-income countries, the low-income countries and African countries, while it is negative for the high-income countries and the MENA countries. Thus, the economic complexity reduces gender inequalities in education at the tertiary level, regardless of the income levels. In fact, in middle-income countries, low-income countries and African countries, the index is less than 1 at the tertiary level of enrollment (see Figures 1 $\& 2$ ). The positive sign signifies that the inequalities decline. In the high-income countries and the MENA countries, the index is greater than 1 (see Figure $1 \& 2$ ). The negative sign signifies that the inequalities decline because that brings the index closer to 1 .

By analyzing the results according to the neoclassical theoretical framework, with the assumption that an increase in trade reduces the female-male wage gap, the developing countries have more raw material endowments. So they are mostly specialized in the export of these products. Economic complexity means that these countries will transform the raw 
materials before exporting them. This requires more skilled and specialized workers. In these conditions, firms working in these sectors will recruit skilled labour, whether male or female. This has two implications. First, this decreases gender inequality in the labour market and increases women's incomes. In this context, women can invest in the education of their children. Second, to make the economy more adapted to the needs of the complexity of the exports, the government will invest in the education system. Therefore, it will lead to the decrease in gender inequalities in education.

The fourth observation is that the control variables reduce the inequalities whatever the level of education, particularly public spending in education, good governance and financial openness by FDI. These results are in conformity with those in the literature (Braunstein, 2006; Boler et al, 2015). The sign of public spending in education is positive and significant in African countries and low-income countries regardless of the level of education. As the index in the gender inequality in education is less than 1 we can deduce that the government has an important role for reducing this type of inequality. Therefore, the role of public expenditure is important in the countries where there is a higher initial level of inequalities. That is not the case in the other countries. Good governance also has a positive and significant sign. Thus, fighting against corruption in a country leads to gender equality in education. To make a parallel with public spending in education, it means that these investments will not be misappropriated for other purposes and will lead to the improvement of the education system for more gender equality. Concerning FDI, the sign is positive and significant in developing countries. Thus, they reduce inequalities. Indeed, foreign companies often bring new managerial styles in favor of gender equality that are adopted by local firms. Also, some studies have shown that more educated women prefer to work in multinational companies that are less unequal. Thus, they can support the education of their children (ILO, 2004; Korinek 2005).

\section{Conclusion}

The descriptive analysis shows that inequalities are higher at the tertiary level than at the primary and secondary levels. The low-income countries are the most unequal. In addition, the scatter plots show a strong correlation between economic complexity and gender inequality in tertiary level enrollment. However, correlation is not causality. For this, we proceed at the empirical analysis using the GMM technique. Based on the neoclassical theoretical framework, the empirical results show that the economic complexity positively impacts the GPI at the primary and secondary levels taking into account the global sample. But, there is no relation between economic complexity and gender inequality in primary and secondary levels enrollment. This second result confirms the observation of no correlation in Figure 5. This difference is because economic complexity needs more workers with a high level of education. Also, the more complex an economy, the more it can reduce its level of inequalities: the result is the same in both samples. Thus, the economic complexity reduces the gender inequalities in education at the tertiary level, regardless of the income levels. In fact, in middle-countries, low-income countries and African countries, the index is less than 1 at the tertiary level of enrollment (see Figures $1 \& 2$ ). The positive sign signifies that the inequalities decline. In high-income countries and MENA countries, the index is greater than 1 (see Figures $1 \& 2$ ). The negative sign signifies that the inequalities decline because that 
brings the index closer to 1 . In addition, public spending in education, good governance and financial openness by FDI reduce gender inequalities in education.

\section{References}

Aditya, A. and A. Acharyya (2012) "Do what countries export matter?" Journal of Economic Development, 37(3): 47-74.

Anderson, F. and K. A. Konard (2003a) "Human capital investment and globalization in extortionary states" Journal of Public Economics 87(7-8), 1539-55.

- (2003b) "Globalization in risky human capital investment" International Tax and Public Finance 10(3), 211-28.

Arora, R.U. (2012) "Gender Inequality, Economic Development, and Globalization: a State level Analysis of India", The Journal of Developing Areas vol. 46, $\mathrm{n}^{\circ} 1$.

Assoumou-Ella, G. (2018) «L'effet direct et indirect de l'inégalité de genre dans l'éducation sur le revenu par tête des pays de la CEMAC », Growth, Employment and Inequalities in Africa Croissance, Emploi et Inégalités en Afrique Proceedings of the Fifth Congress of African Economists, Les Actes du Cinquième Congrès des Economistes Africains.

Badji, M.S. (2008) «Mondialisation et inégalités de genre chez les populations des Etats membres de l'Union Economique et Monétaire Ouest africaine (UEMOA)» cahier de recherche/ Working Paper 08-04.

Baliamoune-Lutz, M. and S.H. Bokoc (2013) "Trade, Institutions, Income and Human Development in African Countries" Journal of African Economies 22 (2): 323-345.

Baliamoune-Lutz, M. (2006) "Globalization and Gender Inequality: Is Africa Different?" Journal of African Economies 16 (2): 301-348.

Baskaran, T., and Z. Hessami (2012) "Public education spending in a globalized world" International Tax and Public Finance 19(5), 677-707.

Barro, R. J. (2013) "Education and Economic Growth" Annals of Economics and Finance Vol. 14(2), Pages 301-328.

Barro, R. J. (1997) "Determinants of Economic Growth: A Cross-Country Empirical Study" The MIT Press, Cambridge, Mass. and London, 1997.

Blundell, R. and S. Bond (1998) «Initial conditions and moment restrictions in dynamic panel data models » Journal of Econometrics 87, 115-143.

Boler, E.A., Javorcik, B. S. and K. H. Ulltveit-More (2015) "Globalization: A woman's best friend? Exporters and the gender wage gap" CESifo Working Paper Series 5296.

Borjas, G. J. and V. Ramey (1995) "Foreign Competition, Market Power, and Wage Inequality" The Quarterly Journal of Economics, 1995, vol. 110, issue 4, 1075-1110.

Braunstein, E. (2006) "Foreign Direct Investment, Development and Gender Equity: A Review of Research and Policy", United Nations Research Institute for Social Development, Occasional Paper 12.

Brummet, Q. (2008) "The Effect of Gender Inequality on Growth: A Cross-Country Empirical Study" The Park Place Economist, vol. XVI.

Esim, S. (2000) "Impact of Government Budgets on Poverty and Gender Equality" InterAgency Workshop on Improving the Effectiveness of Integrating Gender Into Government Budgets, Commonwealth Secretariat, Malborough House, London, 26-27 April 2000.

Felipe J., U. Kumar, Abdon, A. and M. Bacate (2012) "Product complexity and economic development" Structural Change and Economic Dynamics, Volume 23, Issue 1, Pages 36-68.

Felipe, J., Kumar U., and A. Abdon (2010) "How Rich Countries Became Rich and Why Poor Countries Remain Poor: It's the Economic Structure" Levy Economics Institute, WP n0.644, Asian Development Bank. 
Forsythe, N., Korzeniewicz, R. P., Majid, N., Weathers, G., and V. Durrant (2003) Gender inequalities, economic growth and economic reform: A preliminary longitudinal evaluation (No. 2003/45). Geneva: International Labour Office.

Hassan G. and A. Cooray (2013) "Effects of Male and Female Education on Economic Growth: Some Evidence from Asia Using the Extreme Bounds Analysis" Working Papers in Economics 13/10, University of Waikato, Department of Economics.

Hausmann, R and C. Hidalgo (2010) "Country Diversification, Product Ubiquity, and Economic Divergence" Working Paper Series rwp10-045, Harvard University.

Hausmann, R., Hwang J. and Rodrik (2007) "What you export matters" Journal of Economic Growth, 12(1): 1-25.

Hausman R. and B. Klinger (2007) "The structure of the product space and the evolution of comparative advantage" Working Paper Series rwp06-041, Harvard University.

Hidalgo, C. and R. Hausman (2009) "The building blocks of economic complexity", Proceedings of the National Academy of Sciences of the United States of America 106(26): 10570-10575.

Hill, A., and E. M. King (1995) "Women's Education and Economic Well-being” Feminist Economics 1(2): 1-26.

Hoddinott, J. and L. Haddad (1995) "Does Female Income Share Influence Household Expenditures? Evidence from Cote d'Ivoire", Oxford Bulleting of Economics and Statistics, vol. $57, \mathrm{n} 1$.

International Labour Office (2004) A Fair Globalisation: Creating Opportunities for All, Geneva.

Jankowska, A., Nagengast A. and J.R. Perea (2012) "The Product Space and the MiddleIncome Trap: Comparing Asian and Latin American Experiences" OECD Development Centre Working Paper 311.

Khandker, S. R. (1998) "Fighting Poverty with Micro-Credit: Experience in Bangladesh", World Bank, Washington.

Klasen, S. and F. Lamanna (2009) "The Impact of Gender Inequality in Education and Employment on Economic Growth: New Evidence for a Panel of Countries" Feminist Economics, 15(3): 91-132.

Klasen, S. and F. Lamanna (2003) The Impact of Gender Inequality in Education and Employment on Economic Growth in the Middle East and North Africa Mimeographed, University of Göttingen.

Klasen, S. (1994) “'Missing Women Reconsidered”' World Development 22(7): 1061 - 71.

Korinek, J. (2005) "Trade and Gender: Issues and Interactions", OECD Trade Policy Working Paper $n^{\circ} 24$.

McMillan, M., and D. Rodrik (2011) "Globalization, structural change and productivity growth" NBER Working Paper 17143.

Menon, Nidhiya, and Yana Van der Meulen Rodgers (2009) "International trade and the gender wage gap: New Evidence from India's manufacturing sector" World Development 37, no. 5: 965-981.

Mitra, A., Bang, J. T. and A. Biswas (2015) "Gender Equality and Economic Growth: Is it Equality of Opportunity or Equality of Outcomes?" Feminist Economics, vol. 21, Issue 1.

Peridy N., Jouini N. and N. Oulmane (2016) "North African Countries' production and export structure: Towards diversification and export sophistication strategy" Canadian Journal of Development Studies.

Pitt, M. and S. Khandker (1998) "The Impact of Group-based Credit Programs on Poor Households in Bangladesh: Does the Gender of Participants Matter?" Journal of Political Economy, No. 106. 
Poncet S, and M. DE Waldemar (2013) "Export Upgrading and Growth: The Prerequisite of Domestic Embeddedness" World Development Vol. 51, pp. 104-118, 2013.

Roodman, D. (2009) "A note on the theme of too many instruments" Oxford Bulletin of Economics and statistics 71, no. 1: 135-158.

Sajid, S. (2014) "Does Trade Openness Advances Gender Equality in Education: A Case of D8 Countries" J. Glob. \& Sci. Issues, vol. 2, n 2.

Selden, T. M. and M. J. Wasylenko (1995) "Measuring the Distributional Effects of Public Education in Peru.' In: Public Spending and the Poor: Theory and Evidence", edited by Dominique van de Wale and Kimberly Nead, published by Johns Hopkins, Baltimore.

Schultz, T.P. (2006) "Does the Liberalization of Trade Advance Gender Equality in Schooling and Health?" The Institute for the Study of Labor Discussion paper $n^{\circ} 2140$.

Sen, A. 1999. Development as Freedom. New York: Knopf.

Sen, A. (1989) 'Women's Survival as a Development Problem' Bulletin of the American Academy of Arts and Sciences 43(2): $14-29$

Tansel, A., and N. D. Güngör (2012) "Gender Effects of Education on Economic Development in Turkey", IZA Discussion Papers 6532, Institute for the Study of Labor (IZA). Thomas, D., Contreras D. and E. Frankenberg (1997) Child Health and the Distribution of Household Resources at Marriage RAND, and UCLA, California.

Thomas, D. (1990) "Intrahousehold Resource Allocation: An Inferential Approach" Journal of Human Resources, vol. 25

Verschuur, C. and F. Reysoo (2003) Genre mondialisation et pauvreté, Cahiers genre et développement, $N^{\circ} .3$, EFI, Le Harmattan, Genève - Paris.

Yamanura, E. (2016) "Long-Term Effect of International Trade on the Gender Wage and Education Gaps" the Institute of Social and Economic Research Discussion Paper $n^{\circ} 963$.

World Bank (2001) Engendering Development, Washington

World Economic Forum (2010) The Global Gender Gap Report.

\section{Appendix: sample countries and groups by income and region (133 countries)}

High-income economies: Australia, Austria, Bahrain, Belgium, Canada, Chile, Croatia, Cyprus, Czech Republic, Denmark, Equatorial Guinea , Estonia, Finland, France, Germany, Greece, Hong Kong SAR, China, Iceland, Ireland, Israel, Italy, Japan, Korea, Rep., Kuwait, Lithuania, Luxembourg, Malta, Netherlands, New Caledonia, New Zealand, Norway, Oman, Poland, Portugal, Qatar, Russian Federation, Saudi Arabia, Singapore, Slovak Republic, Slovenia, Spain, Sweden, Switzerland, United Arab Emirates, United Kingdom, United States, Uruguay.

Middle-income economies: Albania, Algeria, Angola, Argentina, Armenia, Bolivia, Botswana, Brazil, Bulgaria, Cameroon, China, Colombia, Congo, Rep., Costa Rica, Cote d'Ivoire, Cuba, Djibouti, Dominican Republic, Ecuador, Egypt, Gabon, Ghana, Guatemala, Guyana, Honduras, Hungary, India, Indonesia, Iran, Iraq, Jamaica, Jordan, Lao PDR, Lebanon, Libya, Macedonia, , Malaysia, Mauritania, Mauritius, Mexico, Morocco, Nigeria, Philippines, Romania, Senegal, Serbia, South Africa, Sudan, Swaziland, Syrian Arab Republic, Thailand, Tunisia, Turkey, Ukraine, Venezuela, Vietnam, Yemen.

Low-income economies: Afghanistan, Benin, Burkina Faso, Burundi, Cambodia, Central African Republic, Chad, Congo Dem. Rep., Ethiopia, Gambia, Guinea, Haiti, Kenya, Korea 
Dem. Rep., Liberia, Madagascar, Malawi, Mali, Mozambique, Nepal, Niger, Rwanda, Sierra Leone, Somalia, Tanzania, Togo, Uganda, Zimbabwe.

Africa's economies : Benin, Burkina Faso, Burundi, Cameroon, Central African Republic, Chad, Djibouti, Equatorial Guinea, Ethiopia, Gabon, Gambia, Ghana, Kenya, Liberia, Madagascar, Malawi, Mali, Mauritania, Mozambique, Niger, Nigeria, Rwanda, Sierra Leone, Senegal, Somalia, South Africa, Tanzania, Togo, Uganda, Zimbabwe.

MENA's economies : Algeria, Bahrain, Djibout, Egypt, Iran, Iraq, Israel, Jordan, Kuwait, Lebanon, Libya, Morrocco, Oman, Qatar, Saudi Arabic, Syria, Tunisia, United Arab Emirates, Yemen. 